\title{
THE STUDENTS' SPEAKING ABILITY WITH (ICARE) MODEL
}

\author{
Junaid \\ Prodi Pendidikan Bahasa Inggris, FKIP, Universitas Muhammadiyah Makassar \\ junaid@unismuh.ac.id
}

\begin{abstract}
The research aimed at finding out the improvement of students' speaking ability by using Introduction, Connection, Application, Reflection, Extend (ICARE) Model at Class VIII.B in MTs. Muallimin Muhammadiyah Makassar. The method of this research was Classroom Action Research that consisted of two cycles. One cycle consisted of four meeting. It means that there were eight meeting in two cycles. This classroom action research was done at MTs. Muallimin Muhammadiyah Makassar for English subject. As subject in this research was Class VIII.B in Junior High School in 2012-2013 Academic Years with student's number as about 29 students. Those consist of 29 women. Instruments are speaking test and observation sheet. The findings of this research were the improvement of the students' speaking ability in terms of speaking accuracy and speaking fluency in which the mean score of diagnostic test was 5.17, the mean score of cycle I was 6.06 and the mean score of cycle II was 7.21. The result above indicated that there was significant improvement of the students' speaking ability in terms of speaking accuracy and speaking fluency in the application of form Introductioon, Connection, Application, Reflection, Extend (ICARE) Model at class VIII.B in MTs. Muallimin Muhammadiyah Makassar.
\end{abstract}

Keywords: ICARE Model, Speaking Accuracy, Fluency, Action Research

\section{INTRODUCTION}

The Researcher have experienced when to taught at the eighth-grade students of MTS Muallimin Muhammadiyah Makassar still much of the students which have problems when they are studying of speaking skill. The researcher here tried to the learning strategy or method of teaching English language specially teaching of speaking skill. The are some of learning of teaching be on the students of course the students must be active and creative for example: Quantum Learning, Accelerated Learning, Cooperative Learning, Contextual Teaching and Learning, etc.

After the researcher was reading and understanding some of the strategy to teach students to make be active and creative. So, the researcher was choosing learning CARE Model it able to make all students be active. 
By ICARE Model, students be able to improve speaking ability because they are active when the lesson going on. The important of the speaking skill by Munafath (2010) to speak successfully to spoken language, we need to be able to work out at the material mean when they use particular words in particular ways on particular occasions, and no simply to understand the words themselves.

Besides the problems above the method that the English teacher applies in teaching English is conventional or not effective. The students are provided a piece of paper which contain of a dialogue then they memorize and practice it in front of the class. This way makes students monotonous because they are demanded to focuses on the text. Considering to the reasons above, then the researcher focuses his attention on the speaking ability as one of the skills of language.

The previous research studies onICARE Model are conduct by many scholars Goldman-Easter (1968), Heike (1981), and Nation (1989), Kayi (2006) in Nurhasanah (2008). Their research findings show that repetition is helpful strategy to develop fluency for speaking callss' student who is exposed in term of FormsFocused meaning and Meaning-Focused instruction.

\section{THE CONCEPTS OF SPEAKING}

Byrne (1976:8) states the oral communication is two-way process between the speaker and the listener and in values the productive skill as speaking and receptive skill and listening, so both speaker and listener are active during the oral communication takes place. This means that a speaker may express his/her mind to the listeners later giving response related to the topic they are talking about.

Harmer (1983:130) states that, when two people are engaged in talking to one another, we can be sure that they are in general way to suggest that the speaker makes a decision to address someone. Speaking may be forced on him in some ways but can still say that he wants or intends to speak, otherwise he would keep silent. He has some communicative purposes namely speaker says things because they what something to happen because of what they say. He selects from his language store. The teacher has an alternative capacity to create new sentences if he is a native speaker. 
In relation with the statements above, speaking is a way of conveying message from one person to others. It is the most essential way in which the speaker can express himself through language. Where speaking skill involves fluency and accuracy expression meaning, the exercising of pragmatic or communicative competence and the observance of the rules of appropriateness, all this skill together may be said to make up the global skill of speaking as an act of communication and interaction with other.

Gardner (1992:2) states that speaking is information by giving ideas, asking question and giving responses which have correlation with opinions, or arguments that can stimulate students to support their opinion. It is expected that through the speaking activities, the students can apply their speaking.

Speaking however particularly in English is not easy to do. Gronbeck (2006:334) states that learning to speak is obviously more difficult than larning to understand the spoken language, because it concerns with sequential arrangement of activities that requires on the part of the teacher and the learners. So it is enough for the students to hear or to listen the speech only. Therefore, as students, they have to practice their English anywhere. A teacher should give more attention and give various activities in teaching speaking skill to increase the student ability to use the language because this case is one of the ways to improvestudents' English speaking.

Widdowson(1985:57) states that speaking means of oral communicationin giving impormation which involves two elements, namely the speaker is someone who gives the message and the listener is someone who receives the message. in other word, the communication involves the productive skill of listening.

Widdowson (1985:58) states that an act of communication through speaking is commonly performed in face to face intraction and occurs as part of dialogue or rather from or verbal exchange. Therefore it is depends on an understanding of what else has been said in the interaction.Furthermore, Byrne(1976:8) states that speaking is a means of oral communication in giving ideas or impormation to others. It is the most essential way in which the speaker can express himself through the language. 
Relating to the explanation above, the researcher concludes that speaking is process between speaker and listener giving information each other and both listener and speaker are active during the oral communication takes place. The act of speaking involves not only the production of the sound but also the use of gesture, the movement of the muscles of face, and indeed of the whole body. Allof these non vocal of speaking as a communication activity aretransmitted through the visual medium.

\section{The Element of Speaking}

In speaking, there are some specific elements that have strong correlation with this skill. They are:

\section{Accuracy}

Accuracy in speaking is way of people speaks by using an appropriate vocabulary, pronunciation and grammar. As explained in oxford learner's pocket dictionary (2003:9). Accuracy is the state of being correct or exact and without error, especially as result of careful afford.

According to Harmer (1983:15), aspect of speaking can be divided as follows; Pronunciation is an act or result of production the sound of speech including articulation vowel formation, accent and inflection. Often with reference to some standard of contents or accept proficiency.

\section{Vocabulary}

According to Longman Dictionary of Contemporary English (Longman, 1995:240) vocabularies are all words someone knows, learners or user the words in particularly language a list of words with explanation of their meaning, in a book for learning foreign language.

Harmer in Nurhasanah (2008) distinguishes two types of vocabulary namely active vocabulary and passive vocabulary. According to him active vocabulary is that the students have learned and which they are expected to be able to use. On the other hand, passive vocabulary refers to words which the students will recognize when they met but will probably not be divided in to four kinds as follows: 
1. Oral vocabulary consists of words actively used in speech. These are the words that come readily to one's conversation. The more often a person utters words the words the more readily it will come to his tongue.

2. Writing vocabulary is the words that come readily to one's finger vocabulary.

3. Listening vocabulary is the stock of words to which one responds with meaning and understood in speaking of other.

4. Reading vocabulary is the words that one response in writing of others.

\section{Grammar}

Grammar whose subject matter is the organization of words in to variables communication, often representing many layers of structure, such as phrase sentences, and complete utterance (Munafath, 2010:15). As the fame work to find sentences productively needed. The fact however shows that the learners' mastery or English structure is skill less as found out by some previous researches.

\section{Fluency}

Fluency is the state of being able to speak a language smoothly and easily (oxford learner pocket dictionary, 1995:10) and students are to communicate easily to other friends.

Brown (1980:255) fluency is ready and expressive use of language. It is probably best achieved by allowing the "stream" of speech to "flow" then, assume of this speech spills over beyond comprehensibility to river bank of instruction or same details of phonology, grammar and discourse explained that fluency defined as the ability to across communicative intent without to much hesitation and to many pause or breakdown in communication. It refers to how well you communicate in a natural manner.

\section{Self confidence}

Self-confidence is feeling sure about thing Expressed or done by someone to others. Furthermore confidence is the way we feel about what we are going to do or say. Klippel and Friederike, (1987: 87) states that self-confidence is a mental process which makes someone strong to do or to take action. 


\section{CONCEPT OF LEARNING ICARE MODEL}

There are some of method, strategy, technique and model of learning have in around us, of course be able to improve skill of the students if their used. And the researcher will be using learning ICARE Model for the Classroom Action Research in MTs Muallimin Muhammadiyah Makassar.

According to Aulia (2011) ICARE Model as a model learning system sure needing steps from the planning, implementation, until evaluation. There is stage of planning who preparing the material based on curriculum, and analysis in the class.

Hartoyo (2006) Concept of learning ICARE Model to introduced by Decentralized Basic Education (DBE) who developed by United States Agency International development(USAID) at 2006 year.

ICARE is an abbreviation of Introduction, Connection, Application, Reflection, Extend. The implementation of learning ICARE Model that is;

1. Introduction the teachers' or facilitator to implant knowledge about contents from the lesson. This stage teachers should be explaining objective learning who will have to achieved.

2. Connection from the lesson, the teachers' tried to connecting knowledge of students with new lesson or the teachers could be doing exercise brainstorming is simple to knowing students whether their still remember at the section lesson of before. The teacher here, could be doing presentation or explaining a little. Just moment enough for explaining because the students should be more active learn.

3. Application; this stage is very important from the lesson. After the student gotten information at the stage Connection, students to give opportunity to practice and apply of knowledge. Part application should be long time because this stage the students will be work by individual, pairs, or in groups. The teachers only giving instruction to the students.

4. Reflection this part constitutes of resume from the lesson, and students to choosing for reflection what them has studied. The teacher here to doing 
evaluate to the students, so far result of lesson. This stage also students commanded to explaining what there was studied.

5. Extend; This stage lesson was done, but the students can be using what there was studied. This part the teachers be giving conclude about lesson and be giving home work to students. With this way, students will be using ideas or knowledge of study. John Holt in Hartoyo (2006) said that 'Study process will be improving if students asked for doing something concerned about the lesson who was studied with their own word.

\section{METHOD}

This research followed the principal working of Classroom Action Research (CAR) that contains of four stages, they were: Planning, Implementation of Action, Observation, and Reflection. This research was held around two cycles. They were first and second cycle and each cycle was the series of activities which have close relation. Where, the realization of the second cycle was continued and repaired from the first cycle.

There were two variables in this research namely independent variable and dependent variable. The independent variable of this research was the use of ICARE model in learning speaking. The dependent variable of this research was the improvement of students' speaking skill (accuracy). The indicator of research was the students' speaking accuracy (grammar, vocabulary and pronunciation) can be improved. The subject of research was the students ofMTS Muallimin Muhammadiyah Makassar particularly at class VIII.B, it was located on $\mathrm{Jl}$. Muhammadiyah No. 34 Makassar.

There were two instruments used:

1. Observation sheet

Observation sheet aimed to find out the students' data about their presence and activeness in learning process. The data of the students' activeness was collected based on the following table: 
Table 1. The Student's Active Participation

\begin{tabular}{|c|c|c|l|}
\hline No & $\begin{array}{c}\text { The Students' Active } \\
\text { Participation }\end{array}$ & Score & \multicolumn{1}{|c|}{ Indicator } \\
\hline 1. & Very Active & 4 & $\begin{array}{l}\text { Students respond the material } \\
\text { very active }\end{array}$ \\
\hline 2. & Active & 3 & $\begin{array}{l}\text { Students respond the material } \\
\text { actively }\end{array}$ \\
\hline 3. & Fairly Active & 2 & $\begin{array}{l}\text { Students respond the material } \\
\text { once or twice }\end{array}$ \\
\hline 4. & Not Active & 1 & $\begin{array}{l}\text { Students just sit down during } \\
\text { the activity without doing } \\
\text { something }\end{array}$ \\
\hline
\end{tabular}

(Heaton in Wongso, 2011: 25)

2. Oral Test

Oral Test aimed to get information about students' speaking improvement after teaching and learning process by using ICARE Model.

\section{FINDINGS AND DISCUSSION}

\section{A. Findings}

The findings of the research deals with the answer of the problem statement which it aims to find out the improvement of the students ability in speaking skill. The result of data analysis found that teaching speaking skill through ICARE Model can improve the students' speaking skill in term of accuracy at Eight Grade of MTs Muallimin Muhammadiyah Makassar. Therefore, for the clear explanation about the students' improvement can be seen in the following table.

1. The Improvement of Students' Speaking Skill in Term of Accuracy through ICARE Model

Table 2. The Student's Mean Score in Accuracy

\begin{tabular}{|l|c|c|c|c|c|c|}
\hline \multirow{2}{*}{} & \multicolumn{3}{|c|}{ Score } & \multicolumn{3}{c|}{ Improvement \% } \\
\cline { 2 - 7 } & D - Test & C I & C II & D-T - CI & C I - C II & D-T - C II \\
\hline Accuracy & 5.18 & 6.07 & 7.21 & 17.18 & 18.78 & 39.18 \\
\hline
\end{tabular}

The table above show the mean score of students' achievement in speaking accuracy component. Based on the table, it indicated that the improvement of the 
students' speaking skill through ICARE Model was successful. The students' mean score in d-test was 5.18 classified into Poor score, the students' mean score in cycle I was 6.07 classified into Fair score and the students' mean score in cycle II was 7.21 classified into Good score.

The table also indicated the improvement of the students' speaking ability from D-test to cycle I and cycle II. Where, from D-test to cycle I the improvement of the students' speaking ability was $17.18 \%$, and from D-test to cycle II it improved until $39.18 \%$, whereas from cycle I to cycle II improved until $18.78 \%$.

The improvement of the students' achievement in speaking skill in term of accuracy:

Table 3. The Student's Mean Score of Speaking in Accuracy

\begin{tabular}{|l|c|c|c|c|c|}
\hline \multirow{2}{*}{ Indicator } & \multicolumn{3}{|c|}{ Score } & \multicolumn{2}{c|}{ Improvement \% } \\
\cline { 2 - 6 } & D - Test & C I & C II & D-T - CI & C I - C II \\
\hline Grammar & 5.08 & 6.05 & 7.08 & 19.09 & 17.02 \\
\hline Vocabulary & 5.32 & 6.12 & 7.30 & 15.03 & 19.28 \\
\hline Pronunciation & 5.15 & 6.05 & 7.23 & 17.48 & 19.50 \\
\hline$\sum \mathbf{X}$ & 15.55 & 18.22 & 21.61 & 51.60 & 55.80 \\
\hline $\bar{X}$ & $\mathbf{5 . 1 8}$ & $\mathbf{6 . 0 7}$ & $\mathbf{7 . 2 1}$ & $\mathbf{1 7 . 2 0}$ & $\mathbf{1 8 . 6 0}$ \\
\hline
\end{tabular}

Based on the table, it indicated that the improvement of the students' speaking skill through ICARE model in accuracy was successful. The students' mean score in d-test was 5.18 (Poor), the students' mean score in cycle I was 6.07 (Fair) and the students' mean score in cycle II was 7.21 (Good). So, the improvement of the students' content between d-test and cycle I was $17.20 \%$ and the improvement between cycle I and cycle II was $18.60 \%$. Based on the result of analysis above, it can be conclude that the students' score of cycle I and cycle II was higher than d-test. It means that, there was improved of the students' achievement in speaking in term of accuracy. 
2. The Percentage of Students' Achievement in Speaking Skill through ICARE Model

\section{Accuracy}

The following table and chart show the percentage of students' achievement in speaking skill in term of accuracy before and after application of ICARE Model.

Table 4. The Percentage of Students' Speaking Achievement in Accuracy

\begin{tabular}{|c|c|c|c|c|c|c|c|c|}
\hline \multirow{2}{*}{ No } & \multirow{2}{*}{ Score } & \multirow{2}{*}{ Classification } & \multicolumn{2}{|c|}{ D-test } & \multicolumn{2}{c|}{ Cycle I } & \multicolumn{2}{c|}{ Cycle II } \\
\cline { 4 - 9 } & & & Freq & $(\%)$ & Freq & $(\%)$ & Freq & $(\%)$ \\
\hline 1 & $7.6-8.5$ & Very Good & 0 & 0 & 0 & 0 & 9 & 31.03 \\
\hline 2 & $6.6-7.5$ & Good & 4 & 13.79 & 7 & 24.13 & 19 & 65.52 \\
\hline 3 & $5.6-6.5$ & Fair & 10 & 34.48 & 19 & 65.52 & 1 & 3.45 \\
\hline 4 & $3.6-5.5$ & Poor & 13 & 44.83 & 3 & 10.34 & 0 & 0 \\
\hline 5 & $0-3.5$ & Very Poor & 2 & 6.90 & 0 & 0 & 0 & 0 \\
\hline \multicolumn{3}{|c|}{ TOTAL } & $\mathbf{2 9}$ & $\mathbf{1 0 0}$ & $\mathbf{2 9}$ & $\mathbf{1 0 0}$ & $\mathbf{2 9}$ & $\mathbf{1 0 0}$ \\
\hline
\end{tabular}

The table above showed that in the D-test, there were 2 students $(6.90 \%)$ classified into Very Poor score, 13 students (44.83\%) classified into Poor score, 10 students $(34.48 \%)$ classified into Fair score, 4 students (13.79\%) classified into good score and none of them classified into Very Good score.

The table above also showed that the result of students' speaking skill in accuracy in cycle I and cycle II. In cycle I, none student (00.00)\% classified into Very Poor score, 3 students (10.34\%) classified into Poor score, 19 students (65.52\%) classified into Fair score, 7 students (24.13\%) classified into Good score, whereas, very good score none student. In cycle II none student $(00.00 \%)$ classified into Very Poor score, none student (00.00\%) classified into Poor score, 1 student (3.45\%) classified into Fair score, 19 students (65.52\%) classified into Good score and 9 students $(31.03 \%)$ classified into Very Good score.

3. The Percentage of Students' Achievement in Speaking Skill in Grammar.

The following table and chart show the percentage of students' improvement in speaking in term of Grammar before and after application of ICARE Model. 
Table 5. The Percentage of Students' Speaking Achievement in Grammar

\begin{tabular}{|c|c|c|c|c|c|c|c|c|}
\hline \multirow{2}{*}{ No } & \multirow{2}{*}{ Score } & \multirow{2}{*}{ Classification } & \multicolumn{2}{|c|}{ D-test } & \multicolumn{2}{c|}{ Cycle I } & \multicolumn{2}{c|}{ Cycle II } \\
\cline { 4 - 9 } & & & Freq & $(\%)$ & Freq & $(\%)$ & Freq & $(\%)$ \\
\hline 1 & $7.6-8.5$ & Very Good & 0 & 0 & 0 & 0 & 7 & 24.14 \\
\hline 2 & $6.6-7.5$ & Good & 8 & 27.59 & 15 & 51.72 & 22 & 75.86 \\
\hline 3 & $5.6-6.5$ & Fair & 0 & 0 & 4 & 13.79 & 0 & 0 \\
\hline 4 & $3.6-5.5$ & Poor & 14 & 48.28 & 10 & 34.48 & 0 & 0 \\
\hline 5 & $0-3.5$ & Very Poor & 7 & 24.14 & 0 & 0 & 0 & 0 \\
\hline \multicolumn{3}{|c|}{ TOTAL } & $\mathbf{2 9}$ & $\mathbf{1 0 0}$ & $\mathbf{2 9}$ & $\mathbf{1 0 0}$ & $\mathbf{2 9}$ & $\mathbf{1 0 0}$ \\
\hline
\end{tabular}

The table above shows that in the D-test, there were 7 students $(24.14 \%)$ classified into Very Poor score, 14 students (48.28\%) classified into Poor score, 8 students (27.59\%) classified into Good score, whereas, none of them classified into Fair score and none of them classified into Very Good score.

The table above also shows that the result of students' speaking skill in accuracy component in cycle I and cycle II. In cycle I, none student (00.00\%) classified into Very Poor score, 10 students (34.48\%) classified into Poor score, 4 students (13.79\%) classified into Fair score, and 15 students (51.72\%) classified into Good score, and none student $(00.00 \%)$ classified into Very Good score. In cycle II, none student $(00.00 \%)$ classified into Very Poor score, none student $(00.00 \%)$ classified into Poor score, none student (00.00\%) classified into Fair score, 22 students (75.86\%) classified into Good score, and 7 students (24.14\%) classified into Very Good score.

4. The Percentage of Students' Achievement in Speaking Skill in Vocabulary

The following table and chart show the percentage of students' improvement in speaking skill in Vocabulary before and after application of ICARE Model.

Table 6. The Percentage of Students' Speaking Achievement in Vocabulary

\begin{tabular}{|c|c|c|c|c|c|c|c|c|}
\hline \multirow{2}{*}{ No } & \multirow{2}{*}{ Score } & \multirow{2}{*}{ Classification } & \multicolumn{2}{|c|}{ D-test } & \multicolumn{2}{c|}{ Cycle I } & \multicolumn{2}{c|}{ Cycle II } \\
\cline { 4 - 9 } & & & Freq & $(\%)$ & Freq & $(\%)$ & Freq & $(\%)$ \\
\hline 1 & $7.6-8.5$ & Very Good & 0 & 0 & 1 & 3.45 & 11 & 37.93 \\
\hline 2 & $6.6-7.5$ & Good & 10 & 34.48 & 12 & 41.38 & 17 & 58.62 \\
\hline 3 & $5.6-6.5$ & Fair & 1 & 3.45 & 7 & 24.14 & 0 & 0 \\
\hline 4 & $3.6-5.5$ & Poor & 12 & 41.38 & 9 & 31.03 & 1 & 3.45 \\
\hline 5 & $0-3.5$ & Very Poor & 6 & 20.69 & 0 & 0 & 0 & 0 \\
\hline \multicolumn{3}{|c|}{ TOTAL } & $\mathbf{2 9}$ & $\mathbf{1 0 0}$ & $\mathbf{2 9}$ & $\mathbf{1 0 0}$ & $\mathbf{2 9}$ & $\mathbf{1 0 0}$ \\
\hline
\end{tabular}


The table above showed that in the D-test, there were 6 students (20.69\%) classified into Very Poor score, 12 students (41.38\%) classified into Poor score, 1 student (3.45\%) classified into fair score, and 10 students (34.48\%) classified into Good score, whereas, none of them classified into Very Good score.

The table above also showed that the result of students' speaking skill in vocabulary component in cycle I and cycle II. In cycle I, none student $(00.00 \%)$ classified into Very Poor score, 9 students (31.03\%) classified into Poor score, 7 students (24.14\%) classified into Fair score, and 12 students $(41.38 \%)$ classified into Good score, 1 student (3.45\%) classified into Very Good score. In cycle II, none student (00.00\%) classified into Very Poor score, 1 student $(3.45 \%)$ classified into Poor score, none student (00.00 \%) classified into Fair score, and 17 students $(58.62 \%)$ classified into Good score, whereas, 11 students (37.93\%) classified into Very Good score.

Table 6. The Percentage of Students' Speaking Achievement in Pronunciation

\begin{tabular}{|c|c|c|c|c|c|c|c|c|}
\hline \multirow{2}{*}{ No } & \multirow{2}{*}{ Score } & \multirow{2}{*}{ Classification } & \multicolumn{2}{|c|}{ D-test } & \multicolumn{2}{|c|}{ Cycle I } & \multicolumn{2}{|c|}{ Cycle II } \\
\hline & & & Freq & $(\%)$ & Freq & $(\%)$ & Freq & $(\%)$ \\
\hline 1 & $7.6-8.5$ & Very Good & 0 & 0 & 0 & 0 & 8 & 27.59 \\
\hline 2 & $6.6-7.5$ & Good & 7 & 24.14 & 17 & 58.62 & 21 & 72.41 \\
\hline 3 & $5.6-6.5$ & Fair & 0 & 0 & 2 & 6.90 & 0 & 0 \\
\hline 4 & $3.6-5.5$ & Poor & 18 & 62.07 & 10 & 34.48 & 0 & 0 \\
\hline 5 & $0-3.5$ & Very Poor & 4 & 13.79 & 0 & 0 & 0 & 0 \\
\hline \multicolumn{3}{|c|}{ TOTAL } & 29 & 100 & 29 & 100 & 29 & 100 \\
\hline
\end{tabular}

The table above showed that in the D-test, there were 4 students (13.79\%) classified into Very Poor score, 18 students (62.07\%) classified into Poor score, none student (00.00\%) classified into Fair score, and 7 students $(24.14 \%)$ classified into Good score, whereas, none of them classified into Very Good score.

The table above also showed that the result of students' speaking skill in fluency component in cycle I and cycle II. In cycle I, none student (00.00\%) classified into Very Poor score, 10 students (34.48\%) classified into Poor score, 2 students (6.90\%) classified into Fair score, and 17 students $(58.62 \%)$ classified into Good score. In cycle II, none student (00.00 \%) classified into Very Poor score, none student $(00.00 \%)$ classified into Poor score, none student $(00.00 \%)$ classified 
into Fair score, and 21 students $(72.41 \%)$ classified into Good score, whereas, 8 students $(27.59 \%)$ classified into Very good score.

\section{Observation Result}

The following table and chart showed the observation result of the student's participation in learning speaking of cycle I and cycle II.

Table 7. The Percentage of Students' Participation

\begin{tabular}{|c|c|c|c|c|}
\hline \multirow{3}{*}{ Cycle } & \multicolumn{4}{|c|}{ Students' Participation } \\
\cline { 2 - 5 } & \multicolumn{4}{|c|}{ MEETING (\%) } \\
\cline { 2 - 5 } & $\mathbf{1}^{\text {st }}$ & $\mathbf{2}^{\text {nd }}$ & $\mathbf{3}^{\text {rd }}$ & $\mathbf{4}^{\text {th }}$ \\
\hline Cycle I & $50.93 \%$ & $56.73 \%$ & $60.71 \%$ & $66.07 \%$ \\
\hline Cycle II & $69.44 \%$ & $71.55 \%$ & $76.79 \%$ & $84.48 \%$ \\
\hline
\end{tabular}

Based on the table above, the students' participation was improved. At the first meeting in the cycle I the students' participation was $50.93 \%$ whereas in the last meeting at the cycle II the students' participation was $84.48 \%$.

\section{DISCUSSION}

In this part, the researcher would like to discuss the result of findings. The discussion aimed at describing the students' speaking for accuracy by using ICARE Model.

In the analysis of the students' achievement the researcher found that the mean score of students in speaking skill ICARE Model was improved. The students' score in d-test was 5.18 (Poor), in the cycle I, the students' mean score was 6.07 (Fair) and in the cycle II the students' mean score was 7.21 (Good). The improvement of students' achievement from mean score of D-test and cycle I was 17.18, whereas the improvement of students' achievement from mean score of Dtest and cycle II was 39.18.

The improvement of students' achievement in speaking skill trough ICARE Model had effective effect. The researcher found that before the application of ICARE Model the students' score was 5.08 (Poor) but after application the method the students' score in cycle I was 6.05 (Fair), and in the cycle II became 7.08 (Good). So, the improvement of students' score of D-test and cycle I was 19.09, whereas the improvement of students' achievement of cycle I and cycle II were 17.02 . 
During the teaching and learning process in cycle I, the researcher found that the students were difficult to organize a good speaking skill. There were no relevance or relation between sentences. To solve this problem the researcher had done cycle II and revised the previous lesson plan. In this case, the researcher gave correction activity so the students can correct their speaking each other. The researcher also gave deep explanation about the grammar of a vocabulary, so the students can make a good speaking skill.

From the explanation above the researcher analyzed that the ICARE Model can improve the students' speaking accuracy in grammar in term of vocabulary, where the students' mean score in cycle I and cycle II was higher than d-test.

The improvement of students' achievement in speaking through ICARE Model had effective effect. In the analysis of students' language use the researcher found that before the application of ICARE Model the students' score was 5.32 (Poor). After application of ICARE Model in cycle I the students score was 6.12 (Fair), and in the cycle II the students' score was 7.30 (Good). The improvement of students' achievement from score of d-test and cycle I was 15.04, whereas the improvement of students' score cycle I and cycle II was 19.28.

During the teaching and learning process in cycle 1, the researcher found some student's error in agreement. In this case, the researcher revises the next cycle by rearranging lesson plan. The researcher gave more explanation about correct self-confidence and form group work, so the students can share each other in speaking task. From the explanation above, the researcher analyzed that the students' skill in speaking skill in term of vocabulary by using ICARE Model was improved, where the students' mean score in cycle I and cycle II was higher than d-test.

The researcher also analyzed the percentage of students' progress in speaking skill through ICARE Model. The improvement of students' achievement in speaking skill through ICARE Model had effective effect. The researcher found that before the application of ICARE Model the students' score was 5.15 (Poor) but after application the method the students' score in cycle I was 6.05 (Fair), and in the cycle II became 7.23 (Good). So, the improvement of students' score of D-test 
and cycle I was 17.48, whereas the improvement of students' achievement of cycle I and cycle II were 19.50 .

From the explanation above, the researcher analyzed that the students' skill in speaking skill in term of pronunciation by using ICARE Model was improved, where the students' mean score in cycle I and cycle II was higher than d-test. The researcher also analyzed the percentage of students' progress in speaking skill through ICARE Model. Based on the observation result, the students participation was increased. The students' participation in the first meeting of cycle I was $51 \%$ and in the last meeting of cycle II students participation became $84 \%$. It indicates that the application of ICARE Model can stimulate the students' activeness in teaching and learning process.

\section{CONCLUSION}

Based on the research findings and discussions in the previous chapter, the following conclusions are presented:

1. Using ICARE Model is able to improve the students' speaking accuracy at Class VIII.B of MTs. Muallimin Muhammadiyah Makassar, It is proved by the students' achievement in cycle II is higher than cycle I the students' mean score achievement of the students' speaking accuracy in cycle I is 6.07 and improve become 7.21 in cycle II. That is mean that there is a significant improvement from the cycle I to cycle II, the improvement is $18.78 \%$.

2. Using ICARE Model is able to make the students more active in learning process, especially in speaking activities

3. The process of the teaching and learning process runs well during the classroom action research at the Class VIII.B Students of MTs. Muallimin Muhammadiyah Makassar, because the students are enthusiast to study English. Besides that, the researcher also gets full support by the teachers. 


\section{BIBLIOGRAPHY}

Byrne, Donn.1976. Teaching Speaking Skill. New Edition. London and New York: Longman.

Decentralized Based Education (DBE). 2006. Integrasi Kecakapan Hidup dalam Pembelajaran. USAID Indonesia.

Decentralized Based Education Three (DBE3). 2006. Increased Relevance of Junior Secondary and Non-Formal Education to Work and Life Skills. SC, AED, IRD. Amerika Serikat.

Direktorat Pendidikan Menengah Umum.1999. Penelitian Pembelajaran Bahasa Inggris. Jakarta: Depdikbud

Ellis, R. 1996. The Study of Second Language Acquisition. Oxford: Oxford University Press.

Emzir. 2008. Metodologi Penelitian Pendidikan Kuantitatif dan Kualitatif. Jakarta: PT Raja Grafindo Persada.

Ferrance, Eilleen. 2000. Action Research. New York: Brown University.

Gardner in Val Els, Theo, 1992. Applied Linguistics and the Learning of Foreign Language. London: Edwards Arnold Publisher.

Gay, L.R, 1981. Educational Research; Competencies for Analysis and Application. Columbus: Charcks, E. Merril Publihing Co.

Gronbeck. 2006. Principles of Public Speaking MySpeechLab Series. German: Pearson Allyn \& Bacon.

Hartoyo. 2006. Meningkatkan Keterampilan Mengungkapkan Monolog Descriptive Lisan Sederhana dengan Menggunakan Sistem ICARE. Universitas Negeri Malang.

Harmer, J. 1983. The Practice of English Language Teaching. London and New York Longman Group. 
John, H. Hoover. 1963. Teacher, Parents And Students. Oxford: Oxford University.

Jones, Rhodi. 1989. Speaking and Listening. London: The Bath Press.

Krashen, S. D., \& Terrell, T. D. 1998. The Natural Approach: Language Acquisition in the Classroom. Prentice Hall International.

Kunandar. 2011. Langkah Mudah Penelitian Tindakan Kelas Sebagai Pengembangan Profesi Guru. Jakarta: PT Rajawali Pers.

Larsen-Freeman, D. 1987. Techniques And Principles In Language Teaching. Oxford : Oxford University.

Layman. 1972. Technique in Testing. New York: Oxford University.

Longman. 1995. Input, Interaction and Second Language Acquisition. In Winitz, S. (Ed.) Native Language and Foreign Language Acquisition. New York: New York Academy of Science.

Manser. 1991. Towards The Use of Focus On Form Instruction In Foreign Language Learning And Teaching In Colombia. Ikala vol.16 no.29 Medellín. Retrieved From http://aprendeenlinea.udea. edu. co on 22 July 2012.

Marcel. 1978. Principles of Language Learning and Teaching. Englewood CLIFFS. New Jersey. Particehall Inc. Retrieved From http://www.eric.ed.gov/ERICWebPortal/search/detailmini on 21 July 2012

Munafath. 2010. The Important of the Speaking Skill. Retrieved from: http://www.esgold.com/speaking/information_gap.html. [on 2 April 2010.

Muslich, Masnur. 2009. Melaksanakan PTK itu Mudah. Jakarta: PT Bumi Aksara.

Nishimura, K. 2000. Effective ways of communicative instruction in the Japanese EFL classroom : Balancing fluency and accuracy. Retrieved From 
http://www.eric.ed.gov/ERICWebPortal/search/detailmini on 21 July 2012.

Nunan, D. 1998. Teaching Grammar in Context. ELT journal, 52, 101-109.

Oxford learner's pocket Dictionary. 2003. Oxford: Oxford University Press.

Sauvignon. 1998. Combing Form and Meaning. ELT Journal, 51(4),336 344.

Retrieved from http://eltj.oxfordjournals.org/content/51/4/336.short on 23 July 2012.

Sudjana. 1999. Metode Statistika. Bandung: PT. Gramedia

Webster, 1983. Action Research For Teacher. Cambridge: Cambridge University Press.

Widdowson, H. G. 1985. Teaching language as a communication. Oxford: Oxford University press. 